\title{
CLIL in Pharmacy: \\ A case of collaboration between content and language lecturers
}

\author{
Monika Woźniak \\ mwozniak@usj.es \\ Universidad San Jorge, Spain
}

\begin{abstract}
This paper documents a collaborative work between content and language lecturers for CLIL at a Spanish university. It focuses on the perspectives and concerns of ten Pharmacy lecturers who integrate credits in English within their content subjects, as reflected during a group discussion and in individual questionnaires. The study reveals that the lecturers are motivated and have positive opinions about both the project and the collaboration. In spite of some years of CLIL experience, they still need support and their main difficulties are related to the linguistic side of CLIL and its assessment. Given the differences in objectives in each subject, further collaboration with the language lecturer should focus on addressing the specific needs and concerns of particular lecturers. More collaboration between content lecturers is also needed to define the aims and outcomes of particular activities and to sequence them properly so as to offer a well-balanced CLIL degree programme.
\end{abstract}

Keywords: CLIL, Pharmacy, teacher collaboration, teacher training, teachers' views, university

\section{INTRODUCTION}

Given the widespread use of English in the academic world and the growing interest in internationalising European universities (Graddol 2006), it is not surprising that the number of CLIL (Content and Language Integrated Learning) initiatives is also rising in higher education institutions. In the Spanish context, where there are a large number of universities and a wide array of degree programmes to choose from, CLIL is viewed as a differentiating factor that can also attract new local students, and not only international ones (Dafouz and Núñez 2009: 102, Doiz et al. 2011). With its dual focus on both content and language (Coyle et al. 2010, Mehisto 2008, Mehisto et al. 2008) CLIL teaching at university level has to be planned, delivered, and assessed differently. This is not possible without "an open mind to teaching” (Pavón and Rubio 2010: 50) and a readiness to change teaching methods on the part of the lecturers involved. CLIL classrooms require interaction and dialogue, whereas the lecture format, which may still 
be common in many Spanish universities (Dafouz and Núñez 2009: 104), does not promote cooperative learning and is not able to contribute to the aims of CLIL. The implementation of CLIL at any educational level involves changes not only in the language of instruction but can be a source of additional fears and anxieties for teachers (Pavón and Rubio 2010, Pena and Porto 2008). Higher education is no exception and to address these concerns and to achieve the challenging goals of CLIL, teacher cooperation is also vital at university.

The purpose of this paper is to ascertain teachers' perceptions and experience of their CLIL teaching in English and to document collaborative work between content and language specialists within a degree programme of Pharmacy at a university in Spain. The collaboration is stimulating for both parties and the paper focuses on the experiences of content lecturers who participate in the programme. The study aims to identify the most difficult aspects of CLIL and areas requiring further training and collaboration in order to know how this process should be developed and improved to support and maintain an effective integration of both content and language.

\section{BACKGROUND}

In spite of this dual focus of CLIL on both content and language, as noted by FortanetGómez (2010: 259-260), university content subjects in English are usually taught by content teachers who concentrate first and foremost on achieving the aims established for their subjects. Even if their competence in the L2 is sufficient, they may lack the knowledge and experience in foreign language pedagogy to be able to contribute to their students' language learning and proficiency. It is important for content teachers to be aware of the fact that integrating English does not simply mean translating their classes into English but requires "a combination of the methods used in teaching both the content and the language” (Fortanet-Gómez 2010: 261). The requirement of going beyond a subject-focused mindset and the above-mentioned openness and flexibility in CLIL applies to both content and language teachers (Coyle et al. 2010, Mehisto 2008, Mehisto et al. 2008). Teaching methodologies vary between particular university disciplines and language teachers are not familiar with them. As underscored by Fortanet-Gómez (2010: 264), training courses are often delivered by colleagues from 
the language department of the same university, and "the trainer is assumed to have a better knowledge of English and of language teaching, but not of other aspects such as discipline methodology or methods of assessment”.

Both students and teachers of content subjects are usually non-native speakers of English, so language-focused courses are essential as teachers involved in CLIL projects are mainly concerned about their own fluency in the language required and may not feel well prepared for the project. However, the effectiveness of CLIL does not depend only on the teachers' level of linguistic competence (Pavón and Rubio 2010: 51). Moreover, the levels of the L2 within a given group of students may vary, which creates an additional difficulty for a non-language teacher. In order to overcome these difficulties in supporting language learning by content teachers and the lack of content knowledge by language teachers, the implementation of CLIL should take into account the time teachers need for cooperation so that they can exchange their skills and offer mutual support (Mehisto et al. 2008: 27).

As Fortanet-Gómez (2010: 273) pointed out, all teacher training and collaboration activities within a given institution should be part of a global institutional strategy with clear objectives and recognition of the effort made by the parties involved. Some European universities offer their CLIL lecturers teacher-training courses, usually delivered by language departments (for example, Airey 2011, Fortanet-Gómez 2010, Klaassen 2008), or base their courses taught through the medium of English on close collaboration between content and language lecturers (for example, Bruton and Woźniak 2013, Zegers 2008). Specific training for content teachers is a good occasion for content lecturers from different departments and degree programmes to express and share experiences but a closer, day-to-day collaboration between teachers of nonlinguistic content and language teachers can allow them to address more specific needs and plan teaching strategies together (Mehisto et al. 2008, Tudor 2008: 53).

In the context of Spanish higher education, Dafouz and Núñez (2009: 103-104) found that teachers who deliver courses in English for international students noticed some changes in comparison with their classes in Spanish. Classes taught in English require better preparation and do not leave room for improvisation. Interpersonal skills to attract students' attention, for example, by telling jokes in class, are limited. As for teachers' 
needs and expectations, they mainly need to improve their speaking skills in English as well as call for financial and methodological support. The findings of the interviews with lecturers reported in Aguilar and Rodríguez (2012) show that lecturers are mainly interested in improving their speaking competence in English, but they do not include language issues in the assessment of their students and are not willing to receive any training on the methodology of CLIL teaching. In spite of a longer tradition of teaching in English in northern countries, content teachers seem to have very similar problems. A qualitative study documenting the experiences and impressions of Swedish lecturers from different disciplines shows that they are aware of their limitations when teaching their content courses in English (Airey 2011). Content lecturers consider their English to be "homemade" and do not feel that they should deal with linguistic issues or correct their students' English. Airey argues, however, that it is content teachers who should teach their students disciplinary discourse.

\section{SETTING AND RESEARCH QUESTIONS}

This study was conducted among lecturers of content subjects within the degree in Pharmacy at San Jorge University in Spain (Universidad San Jorge, USJ). According to the university's language policy, English is progressively implemented in all degree programmes. In the first two years of studies at least 1 ECTS (25 hours) in at least three different subjects is taught through the medium of English and from the third year onwards some subjects should be taught entirely in English. One of the key aspects of this CLIL project is a close collaboration between lecturers from particular faculties and English lecturers from the Institute of Modern Languages (IML). The IML also offers courses of general and academic English as well as workshops on CLIL for all teachers involved in the project.

Each content lecturer can count on advice and support from an English lecturer from the IML. The language lecturer is expected to be a methodological advisor and often also coordinates the integration of English in the degree course in question. In the case of Pharmacy, the author of this paper works with all the CLIL lecturers in this degree programme. At the beginning of the academic year the language teacher arranges informal meetings with every content lecturer to talk about the objectives of their 
subjects and to agree on the contents to be taught in English. It is content lecturers who select the contents to be taught in English and the materials to be used. Next, they work with the language teacher on designing activities and tasks, identifying problems that may arise, adapting materials, establishing assessment criteria or analysing past classes and improving lesson plans. Content lecturers receive advice on their language use in class and scaffolding strategies. Lecturers decide if any kind of collaboration is needed in the classroom, for example by delivering the class together as team-teachers or with a language assistant. Full-time content lecturers receive half a credit extra for every credit taught in English. The university also recognises this collaboration in language lecturers' workload by assigning them credits for this purpose. In this case, the number of credits is not fixed and it is adjusted to the needs of a given academic year.

A total of 10 teachers of Pharmacy subjects participate in the CLIL programme and integrate English, to a different extent, in the following 14 subjects (Table 1).

Table 1. Subjects integrating credits in English in the degree of Pharmacy.

\begin{tabular}{|l|l|l|l|}
\hline \multicolumn{3}{|c|}{ Academic year 2012-2013 } \\
\hline Year & Subject & ECTS & ECTS in English \\
\hline 1 & Introduction to Laboratory Work & 6 & 1 \\
\cline { 2 - 4 } & Inorganic Chemistry & 9 & 1 \\
\cline { 2 - 4 } & Organic Chemistry & 9 & 1 \\
\hline 2 & Physical Chemistry II & 6 & 2 \\
\cline { 2 - 4 } & Pharmaceutical Chemistry I & 6 & 0.5 \\
\cline { 2 - 4 } & Pharmaceutical Chemistry II & 6 & 0.5 \\
\cline { 2 - 4 } & Parasitology & 6 & 1 \\
\cline { 2 - 4 } & Human physiology I & 6 & 1 \\
\hline 3 & Human physiology II & 12 & 2 \\
\cline { 2 - 4 } & Pharmaceutical Care II & 6 & 2 \\
\cline { 2 - 4 } & Pathophysiology & 6 & 1 \\
\hline 4 & Pharmacoeconomics I & 6 & 2 \\
\cline { 2 - 4 } & Public Health & 6 & 5.5 \\
\cline { 2 - 4 } & Toxicology & 6 & 5.5 \\
\hline 5 & Pharmacoeconomics II & 6 & 3 \\
\hline
\end{tabular}

Some lecturers teach more than one subject in Pharmacy, for example, Inorganic Chemistry and Pharmaceutical Chemistry I, Organic Chemistry and Physical Chemistry II, and Toxicology, Pharmacoeconomics II and Public Health. 
This paper presents the findings of a focus group discussion and a questionnaire completed by Pharmacy lecturers who deliver at least part of their subject in English. The objectives of the study were the following:

- to find out the perspective of Pharmacy lecturers on the CLIL approach in their degree programme and the collaboration with the IML

- to discern how confident the lecturers feel about teaching their subject in English and to identify the most difficult aspects of CLIL teaching in Pharmacy

- to ascertain content lecturers' training needs and expectations about their future collaboration with the English lecturer

\section{DATA COLLECTION}

As a first step, the author took a qualitative approach to the research questions by means of a discussion group. As Morgan (1997: 2) put it: "the hallmark of focus groups is their explicit use of the group interaction to produce data and insights that would be less accessible without the interaction found in a group”. In this case, the group discussion, sometimes called a focus group interview (Hatch 2002: 134), served as a preliminary stage of the research process that was later used to help develop individual questionnaires and back up the information gathered during the group discussion.

The author of this article, who collaborates with all these CLIL lecturers, was present in the discussion group but her participation was kept to a minimum. The participants were asked to freely express their perspectives and concerns about their CLIL experience. Most of the questions prepared beforehand by the author to be used as prompts did not have to be used, since the discussion setting stimulated memories and ideas and the participants were very willing to verbalise their experiences, reflect on the demands and consequences of CLIL teaching, and share their concerns with their colleagues. In the end the author's main role was to keep the discussion focused on the topic in question. In order to guarantee everybody's equal participation, the discussion took place in Spanish and was similar to a natural conversation between colleagues. The discussion lasted 1 hour and 11 minutes and was audio recorded in its entirety with the consent of the lecturers. The meeting proved to be a good occasion for the lecturers to share their 
experiences and exchange perspectives on our particular context of teacher collaboration and to make suggestions for its further development.

The qualitative data obtained during the group discussion were considered highly relevant and in order to obtain a wider picture of CLIL in Pharmacy, the material was used as a basis for designing individual questionnaires. The questionnaire was divided into three sections and consisted of closed and open questions to gather both quantitative and qualitative data. In the first section personal and background data were collected. The second section aimed to explore individual perspectives and the participants were asked for their opinions about the CLIL experience, its main benefits and their concerns, as well as various aspects of the collaboration with the IML such as its effectiveness, expectations, and suggestions for improvement (Appendix 1). The last section was dedicated to rating the level of difficulty of 27 aspects of CLIL teaching on a scale from 1 to 10 (0 - not difficult at all, 10 - very difficult, Appendix 2). The items were based on the content of the group discussion. The questionnaire was written in English, but the lecturers were given the choice to complete it in English or in Spanish. All questionnaires were completed in English.

The participants in the study were 10 lecturers of Pharmacy subjects (lecturer 1-10) who participate in the CLIL programme at the USJ and integrate English in at least part of their subject. This paper primarily focuses on CLIL in the degree in Pharmacy, but some of the participants also integrate English in other degree programmes, such as Nursing, Physiotherapy or Physical Activity and Sport Sciences. The participants are 7 females and 3 males ranging in age from 30 to 43 years (mean age 35 years). All lecturers are native speakers of Spanish and their declared level of English ranges from B1 to C2. Five of the lecturers attend English courses delivered by the IML, both general and specific (1 lecturer in the B1 course, 2 lecturers in the B2 course, 1 lecturer in the C1 course and Academic Writing, and 1 lecturer in Oral skills). One lecturer receives private English classes at home. They all use English for their research, for example, by reading scientific texts in English. Eight of the participants write their publications in English and five of them give presentations in English at conferences. Seven lecturers have stayed in an English-speaking country for a longer period of time, usually for a few months, mainly for their $\mathrm{PhD}$ research. Two of them lived in an English-speaking country for more than 1 year for professional reasons. In terms of 
experience, they have from 3 to 11 years of experience as university teachers (mean experience 5.7 years). With regard to their CLIL subjects, the participants have from 2 to 9 years' experience teaching their subjects in Spanish (mean 4.22) and from 1 to 4 years in English (mean 2.22 years).

Table 2. Participants, their level of English and years of CLIL experience.

\begin{tabular}{|ll|r|r|r|}
\hline & \multicolumn{2}{|c|}{ Level } & \\
\cline { 3 - 4 } & & B1-B2 & C1-C2 & Total \\
\hline How long have you integrated & $1-2$ years & 3 & 2 & 5 \\
English in your subject(s)? & $3-4$ years & 3 & 2 & 5 \\
Total & & 6 & 4 & 10 \\
\hline
\end{tabular}

In order to provide further insights into the most difficult aspects of CLIL and training needs, the data from the questionnaires were analysed according to lecturers' level of English (B1-B2 or C1-C2) and their experience in CLIL teaching (1-2 years or 3-4 years). In the group of ten lecturers, six have a B1-B2 level and four have a C1-C2 level. In each level group there are three lecturers with 1-2 years of experience and two lectures with 3-4 years of experience as CLIL teachers (Table 2).

\section{DISCUSSION OF RESULTS}

The outcome of the group discussion and open-ended questions will be summarised first. The main issues which emerged from it will be emphasised and supported by citing some illustrative responses from the questionnaire (Questionnaire Part 1). This part will be followed by an analysis of quantitative data (Questionnaire Part 2) taking into account lecturers' level of English and CLIL experience. Given the small number of participants and the aims of the study, the results of the questionnaire were analysed using descriptive statistics without any other processing.

\section{V.1. Responses from the group discussion and Part 1 of the questionnaire}

Overall, lecturers' impressions about CLIL in Pharmacy subjects and the collaboration with the language lecturer are positive. The positive feelings about CLIL expressed during the group discussion and reflected in written responses refer both to themselves as teachers and to their students. As for the reason why they started integrating English 
in their subjects, only one lecturer felt under obligation to participate in the CLIL project. Other lecturers first of all mention the benefits for their students and their future career. Pharmacy students need to be prepared to understand the latest literature and look for information about scientific advances, which nowadays are published mainly in English (Alberch 2000, Hamel 2007).

I integrated credits in English in my subjects because I teach in a scientific degree and nowadays scientific information is in English, everything inside the scientific world is in English. (lecturer 6)

The lecturers with some experience abroad feel that their knowledge and skills acquired in foreign countries are an additional advantage for their students.

It made sense the students could get some benefit from my professional and teaching experience abroad. (lecturer 3)

Apart from the benefits for the students, the lecturers also highlight some personal gains, for example, a chance to maintain or improve their own level of English.

Because it is a challenge and a way to improve the language. (lecturer 1)

Because I want to improve my English and because I think that it's important for the students. (lecturer 2)

One of the most positive aspects of CLIL for the lecturers is overcoming their stagefright and gaining confidence when speaking in English in class. They also notice an improvement in their own language competence (lecturers 1, 2, 3, 8, 9). On the other hand, they also observe benefits for their students as far as students' confidence when using English is concerned and their positive attitude and involvement in the activities developed in their subjects (lecturers 4, 7, 10).

Students are each year less afraid of English activities. (lecturer 10)

(The most positive aspect of my CLIL experience is) To observe the progress of some students and to keep up with my English skills. (lecturer 3)

The lecturers view CLIL as a good opportunity to innovate their teaching (lecturers 4, 7). However, one of the problems with CLIL in higher education is the fear of shallowness of the courses taught in English due to the teachers' inability to express 
some concepts in depth (Airey 2011: 44). Lecturer 1 explains the main concern related to CLIL as follows:

I am not sure if the students can understand the important things of the subject if I am speaking in English. (lecturer 1)

Nevertheless, lecturer 6 points out the need to be more precise in English than in Spanish and notices that students pay more attention in order to understand the content when it is presented in English.

The most positive aspect of my CLIL experience is probably the effort I have to make to explain some abstract concepts in English. Whenever I write in Spanish I tend to use very long sentences with many subordinate clauses. That doesn't happen in English, I must simplify and when I do that students usually understand me better. I have also experienced that if I explain in English students pay more attention. (lecturer 6)

This lecturer adds, however, that explaining scientific concepts in English takes longer and we "cannot afford such a delay". Others, in contrast, complain that their students do not pay enough attention in classes taught in English, especially students with lower levels of English (lecturer 2, 3), or use online translators (lecturer 5).

Lecturers mention more problems and doubts related to their CLIL teaching, for example, their own level of English and the fear that their students will repeat their mistakes (lecturer 1). They feel that their language should be perfect (lecturer 10) and they should be able to answer students' questions about the use of English (lecturer 4). Other problems mentioned were associated with the lack of time or the process of preparing classes in English. During the group discussion the lecturers also mentioned difficulties that cannot be directly related to CLIL but should not be ignored. The lecturers reported difficulties associated with learning styles and some students' lack of transversal skills, for example, group work. This is very important for CLIL settings, as many of the activities are based on cooperative learning. 
Table 3. Training needs (English).

\begin{tabular}{|lc|r|r|r|}
\hline \multirow{2}{*}{ What further training do you need? } & \multicolumn{2}{|c|}{ English } & \multirow{2}{*}{ Total } \\
\cline { 2 - 4 } & No & Yes & 6 \\
\hline \multirow{2}{*}{ Level of English } & B1-B2 & 0 & 6 & 4 \\
& C1-C2 & 4 & 0 & 10 \\
Total & 1-2 years & 4 & 6 & 5 \\
CLIL experience & 3-4 years & 2 & 3 & 5 \\
& & 2 & 3 & 10 \\
\hline
\end{tabular}

As for the training needs and expectations, the lecturers generally express their willingness to learn more. Six lecturers would like to receive more courses on the English language and nine lecturers need more training on the methodology of teaching content in a foreign language. All the lecturers with B1-B2 level would like to receive more training to improve their level of English, regardless of their experience with CLIL, whereas the lecturers with higher levels do not need any additional language courses (Table 3).

In the academic year 2011-2012 the IML offered a series of workshops on CLIL teaching for the lecturers involved in the programme. During the course the lecturers could reflect on and discuss the demands and implications of teaching their subjects in English. Unfortunately, only four lecturers from this study could participate in them.

Table 4.Training needs (Teaching content in English).

\begin{tabular}{|c|c|c|c|c|}
\hline \multirow{2}{*}{\multicolumn{2}{|c|}{ What further training do you need? }} & \multicolumn{2}{|c|}{ Teaching content in English } & \multirow[b]{2}{*}{ Total } \\
\hline & & No & Yes & \\
\hline \multirow[t]{2}{*}{ Level of English } & B1-B2 & 1 & 5 & 6 \\
\hline & $\mathrm{C} 1-\mathrm{C} 2$ & 0 & 4 & 4 \\
\hline \multicolumn{2}{|l|}{ Total } & 1 & 9 & 10 \\
\hline \multirow[t]{2}{*}{ CLIL experience } & 1-2 years & 0 & 5 & 5 \\
\hline & 3-4 years & 1 & 4 & 5 \\
\hline \multicolumn{2}{|l|}{ Total } & 1 & 9 & 10 \\
\hline \multirow{3}{*}{\multicolumn{2}{|c|}{$\begin{array}{l}\text { Did you participate in IML } \\
\text { workshops last year? } \\
\text { Total }\end{array}$}} & 0 & 6 & 6 \\
\hline & & 1 & 3 & 4 \\
\hline & & 1 & 9 & 10 \\
\hline
\end{tabular}


Only one lecturer does not want any further training in the CLIL teaching methodology. This could be because the lecturer has already participated in CLIL workshops mentioned above. Other lecturers, regardless of their level of English and experience, answered that they would like to learn more about CLIL, including those lecturers who had previously participated in the workshops (Table 4). Those who were able to participate particularly appreciated the parts of the workshops dedicated to practising their oral skills, and they would like to receive more training of that kind. They suggested that training sessions should be shorter and more specialised in their subjects and classroom language. Online courses could be an alternative, especially if we take into account that both content and language lecturers are very busy and regular meetings are difficult to arrange. However, in spite of these difficulties, lecturers firmly object to receiving any training online. They call for short and intensive training sessions designed specifically for the degree in Pharmacy and which address their particular communicative needs in class or the laboratory.

\section{V.2. Content teacher difficulties from Part 2 of the questionnaire}

The questionnaire included a section in which lecturers were asked to rate the difficulty of 27 aspects of CLIL derived from the group discussion. This part of the questionnaire aimed to provide further insights into the most problematic parts of CLIL (Table 5).

Table 5. Rate the difficulty of the following aspects of your CLIL teaching on a scale from 0 to 10.

\begin{tabular}{|l|r|r|r|r|r|}
\hline How difficult are these aspects of your CLIL teaching? & $\mathrm{N}$ & min. & max. & Mean & SD \\
\hline 1. selecting the contents of my subject to be taught in English & 10 & 1 & 9 & 4.20 & 2.86 \\
2. finding authentic materials in English to be used in class & 10 & 1 & 8 & 4.10 & 2.47 \\
3. preparing class materials in English (presentations, hand-outs, & 10 & 1 & 9 & 5.30 & 2.50 \\
$\quad$ etc.) & & & & & \\
4. finding adequate words when preparing written materials in & 9 & 2 & 8 & 4.78 & 2.11 \\
English & & & & & \\
5. finding technical terminology in English & 10 & 1 & 8 & 3.80 & 2.20 \\
6. checking English pronunciation of technical terms & 10 & 2 & 9 & 6.10 & 2.03 \\
7. assessing students' level of English & 9 & 5 & 10 & 7.78 & 1.79 \\
8. adapting original English materials to my students' needs & 10 & 1 & 9 & 5.00 & 2.31 \\
9. preparing lecture notes in English & 10 & 1 & 9 & 5.60 & 2.36 \\
10. designing activities in English & 10 & 2 & 9 & 6.30 & 2.36 \\
11. constructing written exams in English & 7 & 2 & 8 & 5.43 & 2.37 \\
12. maintaining the quality of classes similar to that of my classes & 10 & 3 & 10 & 7.50 & 2.42 \\
in Spanish & & & & & \\
13. holding students' interest when teaching in English & 10 & 1 & 9 & 6.30 & 2.76 \\
14. getting my enthusiasm across & 10 & 1 & 9 & 6.00 & 2.83 \\
15. explaining myself clearly in class & 10 & 2 & 10 & 7.20 & 2.35 \\
16. explaining something in different ways & 10 & 2 & 10 & 7.30 & 2.79
\end{tabular}


17. finding adequate words when speaking English in class

18. correcting students' utterances in class

19. reformulating students' utterances in class

20. giving a clear answer to students' questions unprepared

21. giving appropriate examples unprepared

22. reacting to students' actions spontaneously

23. giving linguistic feedback to students

24. correcting students' written work

25. correcting students' oral performance

26. evaluating students' written work

27. evaluating students' oral performance

\begin{tabular}{r|r|r|r|r|}
9 & 2 & 9 & 7.22 & 2.33 \\
9 & 4 & 10 & 8.00 & 2.35 \\
9 & 4 & 10 & 7.00 & 2.29 \\
10 & 3 & 9 & 6.40 & 2.17 \\
10 & 3 & 9 & 6.40 & 2.17 \\
10 & 2 & 10 & 6.40 & 2.67 \\
10 & 4 & 10 & 7.60 & 1.78 \\
9 & 2 & 9 & 7.22 & 2.11 \\
9 & 2 & 10 & 7.00 & 2.50 \\
9 & 3 & 10 & 7.44 & 2.01 \\
9 & 3 & 10 & 7.56 & 2.29 \\
\hline
\end{tabular}

The answers given by Pharmacy lecturers show that the least difficult aspects in Pharmacy are items 5 (finding technical terminology), 2 (finding authentic materials), and 1 (selecting the contents). Even though the means for selecting contents to be taught in English suggests its relative lack of difficulty, during the discussion group mention was also made of the strategies used to select these contents. The lecturers agreed that their responsibility is to achieve content objectives and that they cannot run the risk of the L2 lowering their teaching objectives designated in the study plan. So far the lecturers have been very careful when selecting the contents to be taught in English in order to guarantee the knowledge and competences required in a degree course taught in Spanish. Consequently, English is usually used for assignments where previously learnt knowledge has to be applied and English is rarely taken into consideration to introduce new concepts. This point is particularly important since CLIL should be cognitively challenging and not only consolidate previously acquired knowledge (Coyle et al. 2010, Mehisto 2008, Pavón and Rubio 2010). The choice of contents and materials is made by the content lecturer but the initial ideas are later consulted with the language lecturer, whose suggestions about the linguistic side of the material and tasks are taken into account. All this process requires a common effort and time that the lecturers often do not have. In spite of this collaboration and effort, according to the lecturers, item 12 (maintaining the quality of classes similar to that of my classes in Spanish) is one of the most difficult aspects of CLIL.

It should be mentioned that during the group discussion the lecturers were unanimous about the easy access to authentic materials and specialised references in English that can be used in class. Many of them are not available in Spanish, especially videos or research articles (lecturer 9). Some lecturers, however, underscore the difficulty of finding authentic materials that would be suitable for their teaching objectives and their 
students' needs. The materials available are often not only linguistically but first of all cognitively inaccessible, especially for first-year students. The process of transforming the materials to a pedagogically acceptable form often requires the help of the language lecturer.

Other difficult aspects are related to the linguistic side of CLIL and the problem of assessment and evaluation. In spite of the dual focus of CLIL on both content and language, content lecturers do not usually see themselves as teachers of both content and language. The participants in this study would like their activities to contribute to their students' development of English skills and some of them express concern about not really being able to fulfil this goal. As non-language teachers, they find it difficult to assess their students' level of English (item 7) and thus are not really able to notice students' potential progress in this respect. Their situation is particularly difficult if we take into account the fact that no particular level of English is required of the students at the beginning of their studies. Even though the majority of students of Pharmacy have a command of the language that is sufficient to be able to cope with the proposed activities, there are still students who may find them far above their level. All this creates a complicated situation for the lecturers, who also pinpoint their lack of strategies on how to incorporate the linguistic component of CLIL into scientific contents, not to mention coping with students with different levels of English. The lecturers feel responsible for the development of their students' competences in English, especially in reference to scientific discourse and "bilingual scientific literacy" (Airey and Linder 2008). Another problematic issue is correcting and evaluating students' assignments in English. This mirrors the findings reported in other studies (Aguilar and Rodríguez 2012, Airey 2011: 46-47). The lecturers do not feel prepared to correct students' English and the collaboration with the language lecturer needs to involve collaborative assessment and evaluation.

Table 6 shows the results of rating scales depending on the level of English and the years of CLIL experience of the participants.

Table 6. Results by lecturers' level of English and years of CLIL experience.

\begin{tabular}{|l|lll|l|l|l|l|l|l|l|l|l|}
\hline & \multicolumn{4}{|c|}{ B1-B2 } & \multicolumn{4}{c|}{ C1-C2 } & \multicolumn{3}{c|}{ 1-2 years } & \multicolumn{3}{c|}{ 3-4 years } \\
\cline { 2 - 12 } & $\mathrm{N}$ & Mean & SD & N & Mean & SD & N & Mean & SD & N & Mean & SD \\
\hline 1. & 6 & 4.16 & 2.93 & 4 & 4.25 & 3.20 & 5 & 3.60 & 2.19 & 5 & 4.80 & 3.56 \\
2. & 6 & 5.00 & 2.76 & 4 & 2.75 & 1.26 & 5 & 5.00 & 1.87 & 5 & 3.20 & 2.86
\end{tabular}




\begin{tabular}{|l|lll|lll|lll|lll|}
3. & 6 & 6.50 & 2.07 & 4 & 3.50 & 2.08 & 5 & 5.00 & 3.39 & 5 & 5.60 & 1.52 \\
4. & 5 & 5.80 & 2.17 & 4 & 3.50 & 1.29 & 4 & 4.25 & 2.63 & 5 & 5.20 & 1.79 \\
5. & 6 & 4.67 & 2.50 & 4 & 2.50 & .58 & 5 & 3.60 & 2.70 & 5 & 4.00 & 1.87 \\
6. & 6 & 6.67 & 1.63 & 4 & 5.25 & 2.50 & 5 & 6.60 & 1.82 & 5 & 5.60 & 2.30 \\
7. & 5 & 8.60 & 1.14 & 4 & 6.75 & 2.06 & 4 & 7.75 & 2.06 & 5 & 7.80 & 1.79 \\
8. & 6 & 5.50 & 2.43 & 4 & 4.25 & 2.22 & 5 & 6.00 & 2.00 & 5 & 4.00 & 2.35 \\
9. & 6 & 6.83 & 1.60 & 4 & 3.75 & 2.22 & 5 & 4.60 & 2.97 & 5 & 6.60 & 1.14 \\
10. & 6 & 6.33 & 2.34 & 4 & 6.25 & 2.75 & 5 & 6.60 & 2.19 & 5 & 6.00 & 2.74 \\
11. & 3 & 6.67 & 1.53 & 4 & 4.50 & 2.65 & 3 & 4.00 & 2.65 & 4 & 6.50 & 1.73 \\
12. & 6 & 7.83 & 2.48 & 4 & 7.00 & 2.58 & 5 & 7.20 & 2.28 & 5 & 7.80 & 2.77 \\
13. & 6 & 6.83 & 1.60 & 4 & 5.50 & 4.12 & 5 & 5.60 & 3.13 & 5 & 7.00 & 2.45 \\
14. & 6 & 6.50 & 2.17 & 4 & 5.25 & 3.86 & 5 & 6.00 & 3.16 & 5 & 6.00 & 2.83 \\
15. & 6 & 7.83 & 1.17 & 4 & 6.25 & 3.50 & 5 & 7.00 & 1.58 & 5 & 7.40 & 3.13 \\
16. & 6 & 8.33 & 1.37 & 4 & 5.75 & 3.86 & 5 & 7.20 & 2.77 & 5 & 7.40 & 3.13 \\
17. & 5 & 8.20 & .84 & 4 & 6.00 & 3.16 & 4 & 7.50 & 1.73 & 5 & 7.00 & 2.92 \\
18. & 5 & 8.60 & 1.52 & 4 & 7.25 & 3.20 & 4 & 8.75 & 2.50 & 5 & 7.40 & 2.30 \\
19. & 5 & 6.80 & 1.64 & 4 & 7.25 & 3.20 & 4 & 6.75 & 2.75 & 5 & 7.20 & 2.17 \\
20. & 6 & 6.83 & 1.83 & 4 & 5.75 & 2.75 & 5 & 5.80 & 2.39 & 5 & 7.00 & 2.00 \\
21. & 6 & 6.83 & 1.83 & 4 & 5.75 & 2.75 & 5 & 5.60 & 2.07 & 5 & 7.20 & 2.17 \\
22. & 6 & 7.67 & 1.51 & 4 & 4.50 & 3.11 & 5 & 6.20 & 2.77 & 5 & 6.60 & 2.88 \\
23. & 6 & 8.17 & .98 & 4 & 6.75 & 2.50 & 5 & 7.20 & 1.10 & 5 & 8.00 & 2.35 \\
24. & 6 & 7.67 & .82 & 4 & 6.33 & 3.79 & 4 & 8.00 & .82 & 5 & 6.60 & 2.70 \\
25. & 5 & 8.00 & .71 & 4 & 5.75 & 3.50 & 4 & 6.75 & 2.06 & 5 & 7.20 & 3.03 \\
26. & 5 & 8.00 & 1.42 & 4 & 6.75 & 2.63 & 4 & 6.75 & 2.99 & 5 & 8.00 & .71 \\
27. & 5 & 7.80 & 1.79 & 4 & 7.25 & 3.10 & 4 & 6.75 & 3.30 & 5 & 8.20 & 1.10 \\
\hline
\end{tabular}

Generally, the responses indicate that the participants with a higher level of English found most of the aspects of CLIL less difficult (Figure 1).

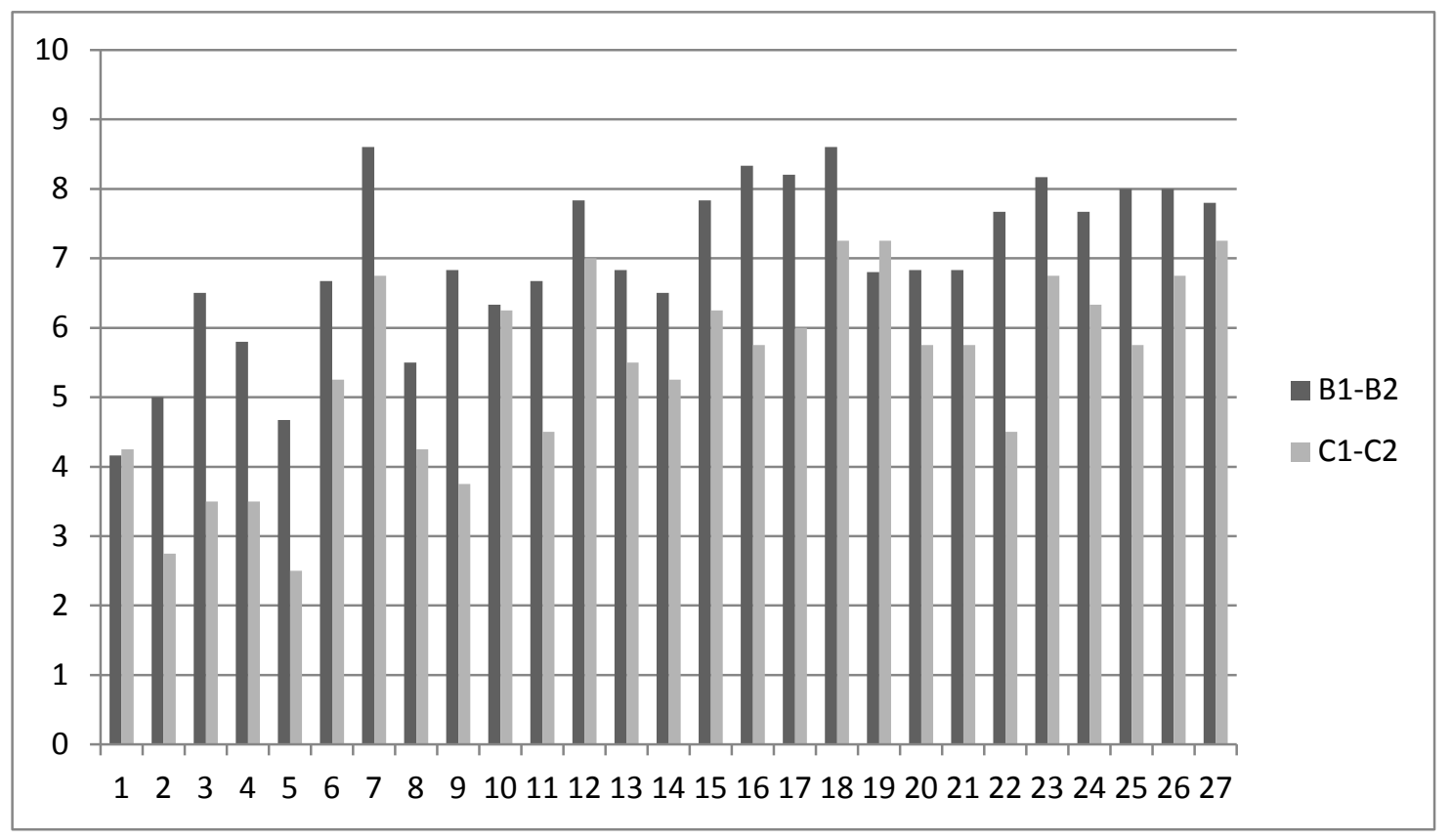

Figure 1. Results by lecturers’ level of English.

However, it can be observed that items 12 (maintaining the quality) and 27 (evaluating students' oral performance) are only slightly less difficult for higher levels and the 
difference is smaller than one point. On the other hand, items 1 (selecting contents) and 10 (designing activities) were rated almost equally difficult regardless of the level, whereas item 19 (reformulating students’ utterances) was rated as even slightly more difficult by higher levels. This difference could be explained by the fact that lecturers with higher levels involve students in speaking activities in class whereas lecturers with lower levels prefer written tasks.

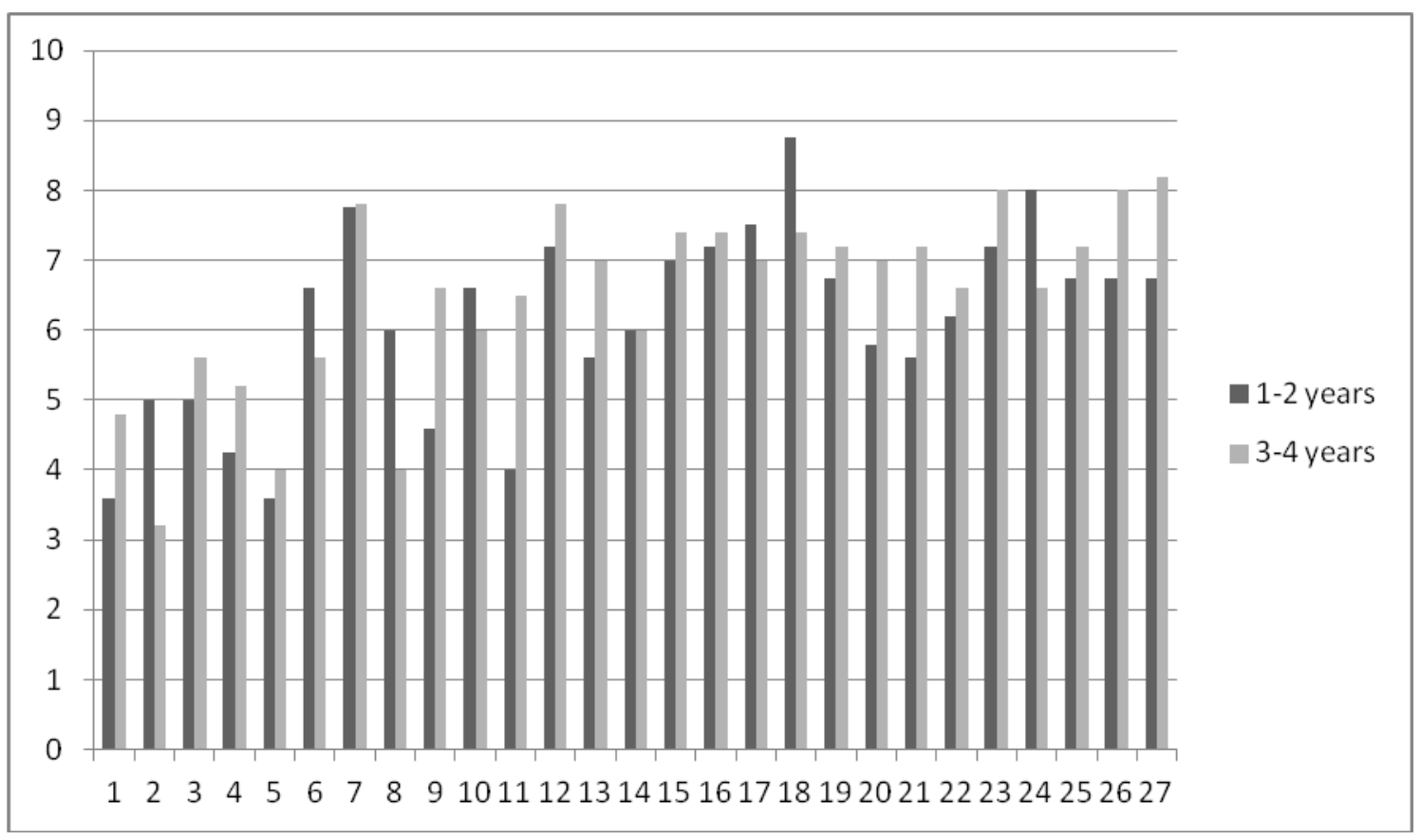

Figure 2. Results by years of CLIL experience.

As for the results according to the years of experience of CLIL teaching (Figure 2), it is more difficult to notice clear differences and draw general conclusions about the two groups. It could be expected that the more experience lecturers have, the easier they find the CLIL approach in their teaching. Indeed, the 1-2 years group found items 2 (finding authentic materials), 8 (adapting original materials), 18 (correcting students' utterances) and 24 (correcting students' written work) much more difficult than their colleagues with more experience. On the other hand, lecturers with 3-4 years' experience rated many items equally or more difficult than their less experienced colleagues. The aspects of CLIL rated considerably higher by the experienced group were items 1 (selecting the contents), 4 (finding adequate words), 9 (preparing lecture notes), 11 (constructing written exams), 13 (holding students' interest), 20 (giving a clear answer), 21 (giving appropriate examples), 23 (giving linguistic feedback), 26 (evaluating students' written work), and 27 (evaluating students’ oral performance). 
Findings from this small-scale study do not allow generalisations to be made about the main difficulties of CLIL teaching and training needs in the context of Pharmacy or higher education. Still, the study indicates that even apparently experienced teachers need methodological support to integrate content and language learning effectively, and this should be taken into account by the university when planning collaborative actions and organizing lecturers’ timetables.

\section{CONCLUSIONS AND IMPLICATIONS}

The research interest of this paper was to document and evaluate the collaborative process between content and language lecturers for CLIL in Pharmacy. The findings illustrate lecturers' subjective perceptions of their CLIL experience in their particular context. Even though the findings provide support for the results obtained in previous studies on teachers' attitudes and concerns about CLIL or bilingual programmes at university, it is difficult to ascertain the extent to which they can be generalised to other university settings. The discussion group and the questionnaires completed by the lectures reveal that in spite of the difficulties and misgivings about particular aspects of CLIL mentioned in this paper and other studies, the standpoint of Pharmacy lecturers towards CLIL is very positive and so is their attitude towards the collaboration with the language lecturer on the design and development of their classes and activities. Pharmacy lecturers emphasise the importance of integrating English for their students' future career and their own professional development as university lecturers. As in many other projects of this kind, the lecturers are very motivated and dedicated, but they complain about lacking time to prepare and carry out their activities and have doubts about their contribution to improving students’ language skills.

The results of this study suggest implications for the future planning of the university's language policy. The findings show that due to a wide variety of subjects and their different objectives it is very difficult to define one general direction of this collaboration. As a result, further work with the language teacher needs to be more personalised and focused on the particular needs of each teacher and the contents delivered in English. Future training programmes should be centred on lecturers' specific communicative needs and address their individual difficulties. The findings 
indicate that even fairly experienced lecturers with a good level of English still need support and further training to integrate content and language learning objectives effectively and maintain the quality of their teaching.

Our next goal is to design a general plan for integrating English throughout the degree programme of Pharmacy. Further collaboration is thus needed to define the objectives and outcomes of particular CLIL activities and sequence them more carefully in terms of their cognitive and linguistic difficulty. The lecturers tend to select safe contents that do not involve much risk of lowering their teaching objectives in case of failure. In the future more of challenging contents should be incorporated with the help of carefully designed scaffolding strategies. A closer collaboration between all the lecturers involved is therefore required to avoid overlaps, to adjust particular objectives to students' academic progress, and to deliver a well-balanced, high-quality CLIL degree programme.

Once implemented, CLIL needs further development and in-service training programmes for both content teachers and language teachers (Fortanet-Gómez 2010). Pharmacy lecturers' opinions about CLIL and their expectations about the collaboration with language lecturers should be taken into consideration when planning the directions of the integration of English in content subjects and the collaboration with the IML. Content lecturers would like to receive more training both in the English language and the methodology of teaching content in English, but they ask for intensive and tailormade courses. As more time for preparation is needed when university subjects are taught in a foreign language (Airey 2011: 44), content lecturers receive extra credits. However, as new teachers join the project every year, a clearer system of credits for language lecturers is needed, taking into account the number of lecturers they work with and the credits they help to integrate. Thanks to the collaboration, both content and language teachers learn from each other, but language teachers also need further training and research on academic and disciplinary language in a given degree programme and how to integrate it in order to maximise the chances of success. 


\section{REFERENCES}

Aguilar, M. and Rodríguez, R. 2012. "Lecturer and student perceptions on CLIL at a Spanish university”. International Journal of Bilingual Education and Bilingualism 15 (2), 183-197.

Airey, J. 2011. “Talking about teaching in English: Swedish university lecturers' experiences of changing teaching language”. Ibérica 22, 35-54.

Airey, J. and Linder, C. 2008. "Bilingual scientific literacy? The use of English in Swedish University Science Courses”. Nordic Journal of English Studies 7 (3), 145-161.

Alberch, P. 2000. "Language in contemporary science: The tool and the cultural icon". In European Commission, Directorate-General for Research and Innovation. Sciences et Langues en Europe. Luxembourg: Office for Official Publications of the European Communities, 249-256.

Bruton, L. and Woźniak, M. 2013. “English for Physiotherapy, Physiotherapy for English: A synergistic approach”. Revista Nebrija de Linguística Aplicada 13, número especial - Actas de Congreso. 1 August 2013 <http://www.nebrija.com/revista-linguistica/revista-linguistica-nebrija13/htm/ BrutonyWozniak.htm>

Coyle, D., Hood, P. and Marsh, D. 2010. CLIL: Content and Language Integrated Learning. Cambridge: Cambridge University Press.

Dafouz, E. and Núñez, B. 2009. “CLIL in higher education: Devising a new learning landscape”. In Dafouz, E. and M.C. Guerrini (Eds.) CLIL across Educational Levels: Experiences from Primary, Secondary and Tertiary Contexts. Madrid/London: Santillana Educación / Richmond Publishing, 101-112.

Doiz, A., Lasagabaster, D. and Sierra, J.M. 2011. “Internationalisation, multilingualism and English-medium instruction”. World Englishes 30 (3), 345-359.

Fortanet-Gómez, I. 2010. “Training CLIL teachers for the university”. In Lasagabaster, D. and Y. Ruiz de Zarobe (Eds.) CLIL in Spain: Implementations, Results and Teacher Training. Newcastle upon Tyne, UK: Cambridge Scholars Publishing, 257-276. 
Graddol, D. 2006. English Next. Why Global English May Mean the End of 'English as a Foreign Language’. London: British Council.

Hamel, R.E. 2007. "The dominance of English in the international scientific periodical literature and the future of language use in science”. AILA Review 20, 53-71.

Hatch, J. A. 2002. Doing Qualitative Research in Education Settings. Albany: State University of New York Press.

Klaassen, R.G. 2008. "Preparing lecturers for English-medium instruction”. In Wilkinson, R. and V. Zegers (Eds.) Realizing Content and Language Integration in Higher Education. Maastricht, Netherlands: Maastricht University, 32-43.

Mehisto, P. 2008. “CLIL counterweights: Recognising and decreasing disjuncture in CLIL”. International CLIL Research Journal 1 (1), 93-119.

Mehisto, P., Marsh, D. and Frigols, M.J. 2008. Uncovering CLIL: Content and Language Integrated Learning in Bilingual and Multilingual Education. Oxford: Macmillan Education.

Morgan, M.B. 1997. Focus Groups as Qualitative Research. 2nd ed. Newbury Park: Sage.

Pavón, V. and Rubio, F. 2010. “Teacher's concerns and uncertainties about the introduction of CLIL programmes”. Porta Linguarum 14, 45-58.

Pena, C. and Porto, M.D. 2008. “Teacher beliefs in a CLIL education project”. Porta Linguarum 10, 151-161.

Tudor, I. 2008. “The language challenge for higher education institutions in Europe, and the specific case of CLIL”. In Martí i Castell, J. and J.M. Mestres i Sierra (Eds.) El Multilingüisme a les Universitats en l'Espai Europeu d'Educació Superior: (Actes del seminari del CUIMPB-CEL 2007). Barcelona: Institut d'Estudis Catalans, 41-64. 1 August $2013<\underline{\text { http://publicacions.iec.cat/repository/ }}$ pdf/00000054\%5C00000051.pdf>

Zegers, V. 2008. "When European studies meet English: A practitioner's view on content and language integrated learning". In Wilkinson, R. and V. Zegers (Eds.) Realizing Content and Language Integration in Higher Education. Maastricht, Netherlands: Maastricht University, 228-236. 
Received: 31 May 2013

Accepted: 7 August 2013

Cite this article as:

Woźniak, M. 2013. "CLIL in Pharmacy: A case of collaboration between content and language lecturers”. Language Value 5 (1), 107-128. Jaume I University ePress: Castelló, Spain. http://www.e-revistes.uji.es/languagevalue. DOI: http://dx.doi.org/10.6035/LanguageV.2012.5.6

ISSN 1989-7103

Articles are copyrighted by their respective authors

\section{APPENDIX 1}

\section{Questionnaire (Part 1)}

- Why did you start integrating credits in English in your subject(s)?

- What is the most positive aspect of your CLIL experience?

- What is your major problem or concern about CLIL in your subject(s)?

- What are the most effective aspects of the collaboration with the IML?

- What are the least effective aspects of the collaboration with the IML?

- How could this collaboration be improved?

- What further training do you need?

\begin{tabular}{|l|l|}
\hline & - English \\
\hline & - methodology of teaching content in English \\
\hline & - other (specify): ............ \\
\hline & - none \\
\hline
\end{tabular}

- Did you participate in the workshops offered by the IML last year?<smiles>[Mg]C1CCC1</smiles>

What was the most useful part of the workshops? 


\section{APPENDIX 2}

\section{Questionnaire (Part2)}

How difficult are these aspects of your teaching in English (1 - not difficult at all, 10 - very difficult)?

\begin{tabular}{|l|l|l|l|l|l|l|l|l|l|l|}
\hline & $\mathbf{1}$ & $\mathbf{2}$ & $\mathbf{3}$ & $\mathbf{4}$ & $\mathbf{5}$ & $\mathbf{6}$ & $\mathbf{7}$ & $\mathbf{8}$ & $\mathbf{9}$ & $\mathbf{1 0}$ \\
\hline $\begin{array}{l}\text { 1. } \\
\text { selecting the contents of my subject to be taught in } \\
\text { English }\end{array}$ & & & & & & & & & \\
\hline
\end{tabular}

2. finding authentic materials in English to be used in class

3. preparing class materials in English (presentations, hand-outs, etc.)

4. finding adequate words when preparing written materials in English

5. finding technical terminology in English

6. checking English pronunciation of technical terms

7. assessing students' level of English

8. adapting original English materials to my students needs

9. preparing lecture notes in English

10. designing activities in English

11. constructing written exam in English

12. maintaining the quality of classes similar to that of my classes in Spanish

13. holding students' interest when teaching in English

14. getting my enthusiasm across

15. explaining myself clearly in class

16. explaining something in different ways

17. finding adequate words when speaking English in class

18. correcting students' utterances in class

19. reformulating students' utterances in class

20. giving a clear answer to students' questions unprepared

21. giving appropriate examples unprepared

22. reacting to students' actions spontaneously

23. giving linguistic feedback to students

24. correcting students' written work

25. correcting students' oral performance

26. evaluating students' written work

27. evaluating students' oral performance

28. other (specify) ................. 